\section{Späth loss rocks universities}

\section{Munich}

Germany was rocked last week by the sudden resignation of Lothar Späth, the prime minister of the Land (state) of Baden-Würtemberg, who was known during his 12 years in office as a champion of high-technology industry and of science and technology at universities. Under Späth's guidance, Baden-Würtemberg became a base for modern industry that has in large part been responsible for the German economic strength of the past decade.

Späth resigned amid controversy after a series of damning articles appeared in the news magazine Der Spiegel alleging that he had taken a series of extravagant holidays in the Aegean and the Far East paid for by local industrialists, including executives of the electronics company SEL and the toothpaste company Blendax.

Späth denies that he was compromised by accepting the holidays. According to newspaper reports, he said in a hastily called press conference on 13 January that though there may have been "clumsiness in one or another case", he never lost his "inner independence" as prime minister. Before the scandal, he was thought to be one of the strongest competitors of Helmut Kohl for the office of national party chairman and a potentially strong candidate for chancellor.

Späth had come to see himself as the embodiment of Baden-Würtemberg and the best proponent for its high-tech future, apparently blinding him to the appearance of impropriety in his actions. The news magazine Stern wrote last week that he "ran Baden-Würtemberg like a well-oiled high-tech company".

Credited with almost single-handedly bringing to Baden-Würtemberg such important institutions as the Centre for Molecular Biology in Heidelberg (ZMBH), Späth also brought supercomputers to universities in Stuttgart and Karlsruhe. No less important, Späth stood up for smaller projects in humanities such as a department of Japanese studies in Heidelberg, which he saw as essential to building stronger economic ties to Japan. "You could always count on Späth if you needed a few million quickly for a special project", says one university researcher.

Späth will be replaced in office by Erwin Teufel, who for the past 12 years has been head of the party caucus for Späth's party, the Christian Democratic Union, in the parliament of BadenWürtemberg. Teufel, 51 years old, served briefly as Interior Minister and Minister for Agriculture and Environment in the 1970 s. Like Späth, he is a career politician with a degree from a polytechnic (Fachhochschule) in administration.
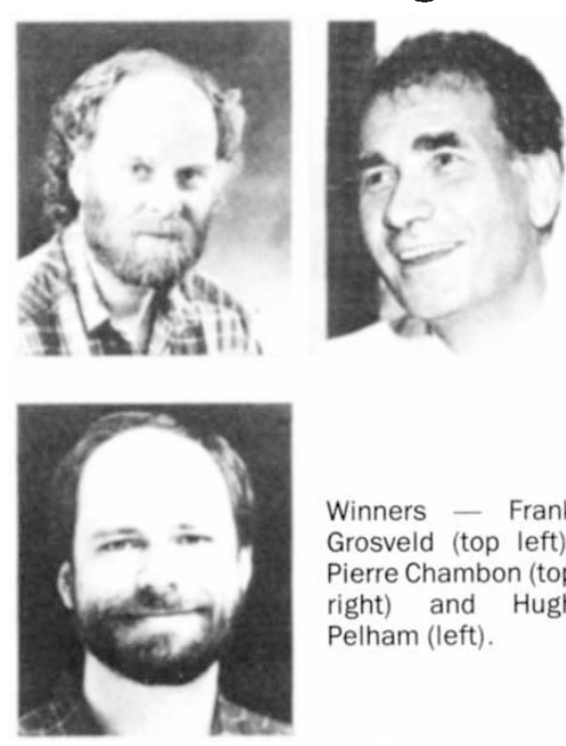

Winners - Frank Grosveld (top left), Pierre Chambon (top right) and Hugh Pelham (left).
Researchers say that Späth's departure will have an unpredictable impact on science in Baden-Würtemberg. Although it is hard to imagine anyone campaigning as hard for science and technology as Späth did, he neglected more mundane areas, such as general university budgets. Researchers hope Teufel will have a steadying influence on the government of Baden-Würtemberg after Späth's mercurial management style.

For example, year after year for the past ten years, universities had inflicted on them a reduction in their budgets which, GULF CONFLAGRATION

\section{Predicting climate problems}

\section{London}

THE climate in the immediate region of Kuwait could be disrupted and the SouthEast Asian summer monsoon rainfall reduced if a large number of Kuwait's oil wells are set alight during the current hostilities, the UK Meteorological Office has concluded. But a global climatic disaster is unlikely, according to the preliminary analysis of the environmental effects of a conflagration, released by the British Ministry of Defence last week.

The Meteorological Office study was asked for by the British government after participants in a meeting in London predicted that sabotage of Kuwaiti oil wells could severely disrupt the regional, and even the global climate (see Nature 349, 96 ; 10 January 1991). It assumes that 80 million tonnes of Kuwaiti oil could burn over one year, if most wells are set alight.

Acid rain could be heavy in and around Kuwait, the Meteorological Office says, though small in absolute terms (an average of DM2.5 million a year at a university the size of that in Heidelberg, which has an annual budget of roughly DM200 million), dramatically reduced the amount of money that could be freely invested by university administrators in additional research equipment and overhead costs.

In the interests of stability, Teufel is expected to take over the two-year budget plan for Baden-Würtemberg that was about to be agreed before Späth resigned, according to CDU spokesman Gerhard Winter. He will then make changes, to be financed by supplementary budgets, as he sees fit.

Steven Dickman
The cloud of soot is the main uncertainty. Close to Kuwait, the blocking of sunlight is likely to cause "a considerable reduction" in daytime temperature, but the Meteorological Office predicts only a small effect globally. To depress the temperature in regions remote from Kuwait, the soot must first rise into the upper atmosphere. This depends on the size distribution of the soot particles and how quickly the soot is washed out of the atmosphere by rain, each of which is difficult to estimate.

But even a localized blocking of sunlight could reduce the heating that feeds the South-East Asian monsoon winds. Disruption of the monsoon raises the spectre of a drought in a highly populous region, but the Meteorological Office stresses that the monsoon system is very variable, making detailed predictions impossible.

Peter Aldhous

\title{
Chambon among winners of Swiss prize
}

\section{London}

ThE sixth Louis Jeantet Prize for Medicine, worth 1.95 million Swiss Francs, will be shared by three scientists: Pierre Chambon of the University of Strasbourg, Frank Grosveld of the National Institute for Medical Research in London and Hugh Pelham at the Medical Research Council Laboratory of Molecular Biology in Cambridge, United Kingdom. Chambon is recognized for work on gene expression, and is currently involved in the molecular biology of breast cancer. Grosveld, who is a Dutch citizen, is working on globin gene expression, whereas Pelham's group works on heat shock proteins and intracellular membrane traffic. All three researchers will use the prize, to be presented in Geneva on 19 April, to expand their research teams and buy new equipment.
Henry Gee 